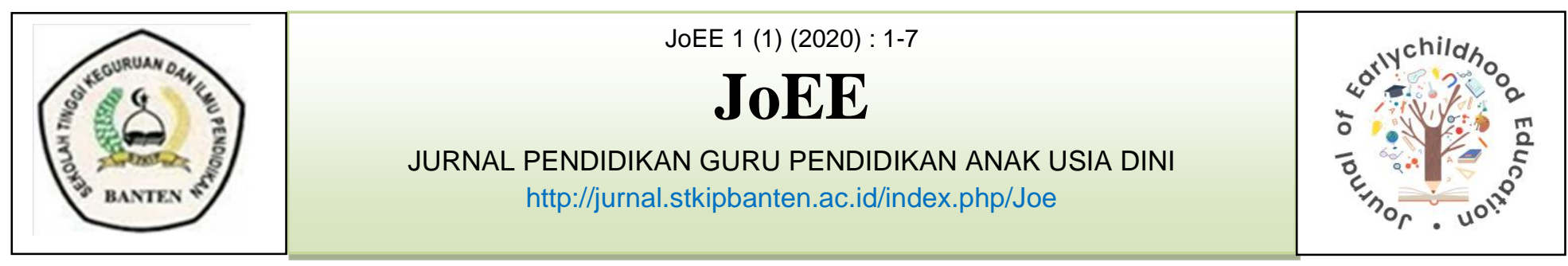

\title{
PENGGUNAAN MEDIA KARTU ANGKA UNTUK MENINGKATKAN KEMAMPUAN KOGNITIF (BERHITUNG) PADA ANAK USIA DINI
}

\author{
Tubaus Rahman \\ tubagusrahman87@gmail.com \\ Pendidikan Guru Pendidikan Anak Usia Dini \\ Sekolah Tinggi Keguruan dan Ilmu Pendidikan Banten
}

\begin{abstract}
Pendidikan Anak Usia Dini adalah pendidikan yang diselenggarakan dengan tujuan untuk memfasilitasi pertumbuhan dan perkembangan anak secara menyeluruh atau menekankan pada pengembangan seluruh aspek kepribadian anak. Tujuan penelitian ini adalah Untuk mengetahui hasil perkembangan kognitif (berhitung) pada anak usia dini setelah dilakukanpenerapan permainan kartu angka. Adapun Peneltian ini adalah penelitian kepustakaan (Library Research), Jadi dari hasil penelitian literatur dengan pendekatan pembelajaran pengguna media kartu angka untuk meningkatkan kemampuan kognitif (Berhitung) Anak usia dini meningkat dengan selisih 26\%. Adapun kesimpulan dari penelitian ini adalah terdapat peningkatan menggunakan media Penggunaan Media Kartu Angka terhadap Kognitif (Berhitung) Pada Anak Usia Dini.
\end{abstract}

Kata Kunci: Media Kartu Angka, Kemampuan Kognitif(Berhitung).

\section{Pendahuluan}

Anak usia dini merupakan usia yang sangat menentukan dalam bentuk karakter dan kepribadiannya. Pada masa ini sering disebut masa "Golden Age". Pendidikan anak usia dini adalah suatu upaya pembinaan yang ditujukan kepada anak sejak lahir sampai dengan usia 6 tahun yang dilakukan melalui pemberian rangsangan pendidikan untuk membantu pertumbuhan dan perkembangan jasmani dan rohani agar anak memiliki kesiapan dalam memasuki pendidikan lebih lanjut (UU No. 20 Tahun 2003 pasal 1 ayat 14).

Teori perkembangan kognitif menurut Piaget dalam Santrock menyatakan bahwa anak secara aktif membangun pemahaman mengenai dunia dan melalui empat tahapan perkembangan kognitif. Adapun empat tahapan perkembangan kognitif tersebut adalah (1) tahap sensori motor (Usia 0-2 tahun), (2) tahap praoperasional (usia 2-7 tahun), (3) tahap operasional konkret (usia 7-11 tahun), (4) tahap operasional formal (usia 11 keatas).jhon santrock 48:2012)

Berdasarkan data pra observasi di lapangan ditemukan daftar anak TK Nurul Falah Ciayun terdapat 43 orang anak yang tercatat sebagai murid di TK Nurul Falah Ciayun tersebut. Dari ke 43 anak itu yang menjadi objek dalam 
penelitian ini adalah anak kelas B2 yang berjumlah 15 anak. Dimana anak-anak tersebut yang menjadi objek dalam penelitian

ini, anak-anak tersebut memiliki kemampuan kognitif yang berbeda-beda dan masih belum berkembang dengan baik. Hal ini terlihat pada saat guru mengajak anak menyebutkan lambang bilangan dan huruf, sebagian anak belum dapat menggunakan simbol atau benda untuk menyebutkan lambang bilangan, dan anak masih bingung mengklasifikasikan benda berdasarkan warna, bentuk dan ukuran,. Karena guru selalu menggunakan media papan tulis yangmembuat anak kurang menarik sehingga perkembangan kognitif dalam mengembangkan bilangan atau angka belum maksimal.

Pernyataan diatas sebagai alternatif peneliti menggunakan media kartu angka. Kartu angka adalah gambar yang dituangkan pada selembar karton berbentuk kartu yang cukup besar, kartukartu tersebut memuat angka yang ditulis biasanya disertai gambar. Kartu angka dapat berbentuk prsegi panjang, bujur sangkar,dan kotak yang berisi tanda atau lambang sebagai ganti bilangan. (Nunik 1:2009)

Menurut Caphin dalam Susanto bahwa kemampuan kognitif adalah suatu proses berfikir, daya menghubungkan, kemampuan menilai dan mempertimbangkan. Sedangkan menurut Susanto berpendapat, kognitif merupakan "suatu proses berfikir yaitu kemampuan individu untuk menghubungkan, menilai dan mempertimbangkan suatu kejadian atau peristiwa. (Ni luh Wayan 4:2016)

Dari latar belakang tersebut, peneliti ingin terdorong untuk melakukan suatu penelitian dengan judul "Penggunaan Media Kartu Angka Untuk Meningkatkan Kemampuan Berhitung Anak Usia Dini".

Adapun rumusan masalah dalam penelitian ini adalah, Pertama Bagaimana penggunaan media pembelajaran kartu angka untuk meningkatkan kemampuan kognitif berhitung anak usia dini? Kedua, Bagaimana hasil perkembangan kognitif (berhitung) pada anak usia dini setelah dilakukan penerapan permainan kartu angka?

Adapun tujuan penelitian ini dalalah pertama, Untuk mengetahui penggunaan media pembelajaran kartu angka untuk meningkatkan kemampuan kognitif berhitung anak usia dini kedua, Untuk mengetahui hasil perkembangan kognitif (berhitung) pada anak usia dini setelah dilakukan penerapan permainan kartu angka. Media Kartu Angka merupakan salah satu langkah mudah untuk menunjang proses mengajar siswa dikelas untuk memberikan rangsanganrangsangan terhadap anak melalui media seperti media kartu angka bergambar. Menurut Kemmis, 1997 (dalam Wayan) Kartu angka bergambar adalah kertas tebal, berbentuk persegi panjang, bujur sangkar dan kotak yang berisi tanda atau lambang sebagai ganti bilangan dan gambar. Mayke 1995 (dalam Wayan) yang menyatakan bahwa "belajar dengan bermain kartu angka memberi kesempatan kepada anak, mengulang-ngulang, menemukan sendiri, bereksplorasi, mendapatkan bermacam-macam konsep serta pengertian yang tidak terhitung banyaknya"

Menurut Azhar Asyad 2007 dalam bukunya Fahmi kata media berasal dari bahasa latin Medius yang secara harfiah berarti tengah merupakan bentuk jamak dari kata medium yang secara harfiah artinya tengah, perantara, atau pengatar.(Fahmi 83:2015) Kata media berasal dari bahasa latin yang merupakan bentuk jamak kata "medium" yang secara harfiah berarti "perantara atau pengantar pesan dari pengirim kepada penerima pesan. Sedangkan dalam Kamus Besar Bahasa Indonesia, media diartikan sebagai alat (sarana) komunikasi seperti: koran, majalah, radio, televise, film, poster dan spanduk (Sudarman 6:2006). Sedangkan dalam Besar Bahasa Indonesia, media 
diartikan sebagai alat (sarana) komunikasi, seperti koran, majalah, radio, televise,

film, poster dan spanduk. Kartu angka yang digunakan dalam penelitian ini adalah alat peraga atau media yang digunakan untuk proses belajar mengajar dalam rangka mempermudah atau memperjelas penyampaian materi pelajaran. Kartu huruf yang berfungsi untuk mempermudah anak dalam pemahaman suatu konsep sehingga prestasi pembelajaran lebih menyenangkan dan lebih efektif. media atau alat peraga adalah sesuatu yang dapat diinderakan yang berfungsi sebagai perantara (Sarana atau alat untuk proses komunikasi / proses belajar mengajar).

Kognitif adalah proses yang terjadi secara internal di dalam pusat susunan syaraf pada saat manusia sedang berfikir (martini 2016: 18). Istilah cognitive berasal dari kata cognition yang padananya knowing, berarti mengetahui. Dalam arti yang luas, cognition (kognisi) ialah perolehan, penataan, dan penggunaan pengetahuan. Dalam perkembangan selanjutnya, istilah kognitif menjadi popular sebagai salah satu domain atau wilayah/ranah psikologis manusia yang meliputi setiap perilaku mental yang berhubungan dengan pemahaman, pertimbangan, pengolahan informasi, pemecahan masalah, kesengajaan, dan keyakinan.

Perkembangan kognitif mengacu pada perkembangan anak dalam berpikir dan memberikan kemampuan untuk memberikan alas an. Carton dan Allen dalam Yuliani (2014) menggambarkan perkembangan kognitif sebagai kapasita untuk bertumbuh untuk menyampaikan dan menghargai maksud dalam penggunaan beberapa system symbol yang secara kebetulan ditonjilkan dalam suatu bentuk pengaturan. System symbol ini meli-puti kata-kata, gambaran, isyarat, dan angka-angka (Sujiono 17:2010) menurut Piaget, perkembangan kognitif bertujuan untuk memperoleh struktur-struktur psikologis yang diperlukan supaya manusia mampu berfikir secara logis dan mampu mengadakan penalaran secara abstrak mengenai masalah-masalah actual dan hipotesis. Piaget memandang anak sebagai organisma aktif yang berkembang dengan impuls-impuls internal dan polapola perkembangan tertentu" (Sumanto 152:2014)

Kant, sebagai moyang aliran kognitif, menyimpulkan bahwa jiwalah yang menjadi alat utama pengetahuan, jiwalah yang menafsirkan secara aktif pengalaman indriawi. Jiwalah yang menafsirkan, mendistorsi, dan mencari makna. Tidak selamanya kita merespons stimuli eksternal. Aliran kognitif lebih dekat dengan aliran tasawuf dalam islam yang menyatakan bahwa pengetahuan yang ditemukan jiwa dijamin aman (Mahmud, 39:2009).

Berdasarkan beberapa pengertian diatas dapat dipahami bahwa kognitif atau pemikiran merupakan istilah yang digunakan oleh para ahli psikologi yang berhubungan dengan pikiran yang memungkinkan memperoleh pengalaman serta mampu memcahkan masalah yang dihadapi dalam proses kehidupan manusia dan dikenalkan sejak dini.

\section{METODE}

Metode Penelitian yang dilakukan menggunakan Penelitian Literatur. Dalam melakukan penelitian ilmiah harus dilakukan teknik penyusunan yang sistematis untuk memudahkan langkahlangkah yang akan diambil. Begitu pula yang dilakukan penulis dalam penelitian ini, langkah pertama yaitu dengan melakukan studi literature pada buku-buku yang membahas tentang penggunaan media Kartu Huruf untuk meningkatkan Kognitif berhitung AUD, jurnal dan penelitian yang didapat dari studi literature ini akan digunakan sebagai acuan untuk membuat penelitian.

Adapun Teknik Pengumpulan Data dalam penelitian ini adalah data primer dan sekunder. Data primer yaitu data yang dikumpulkan dan diolah sendiri 
oleh peneliti langsung dari subjek atau objek penelitian. Data primer yang digunakan dalam penelitian ini adalah reduksi data, display data dan penarikan kesimpulan. Sedangkan Data sekunder merupakan data yang diperoleh bukan dari pengamatan langsung. Akan tetapi data tersebut diperoleh dari hasil penelitian yang telah dilakukan oleh penelitipeneliti terdahulu. Sumber data sekunder yang dimaksud berupa buku dan laporan ilmiah primer atau asli yang terdapat di dalam artikel atau jurnal (tercetak dan/atau non-cetak) berkenaan dengan penggunaan media kartu angka dan peletakannya dalam aktivitas pembelajaran.

Teknik Analisis Data daalam peneitian ini Analisis data merupakan upaya mencari dan menata secara sistematis data yang telah terkumpul untuk meningkatkan pemahaman penelitian tentang kasus yang diteliti dan mengkajinya sebagai temuan bagi orang lain (Neong muhadjir dalam yuni irawati, 28:2013).

Analisis data yang digunakan dalam penelitian ini adalah analisis anotasi bibliografi (annotated bibliography). Anotasi berarti suatu kesimpulan sederhana dari suatu artikel, buku, jurnal, atau beberapa sumber tulisan yang lain, sedangkan bibliografi diartikan sebagai suatu daftar sumber dari suatu topik. Pertama, Reduksi Data. Dalam kaitan ini peneliti mereduksi data yang telah didapat dari hasil observasi dan wawancara dan dirangkum satu per satu agar memudahkan peneliti dalam memfokuskan data. Data yang tidak terkait dengan permasalahahan tidak disajikan dalam bentuk laporan. Kedua, Display Data. Setelah data direduksi maka langkah selanjutnya adalah menyajikan data (Display Data). Data yang berupa tulisan tersebut disusun kembali secara baik dan akurat untuk dapat memperoleh kesimpulan yang valid sehingga lebih memudahkan peneliti dalam memahami. Penyajian data dalam penelitian kualitatif berbentuk uraian yang singkat dan jelas. Ketiga Menarik Kesimpulan Penarikan kesimpulan merupakan bagian dari aktivitas data. Aktivitas ini dimaksudkan untuk memberikan makna terhadap hasil analisis, menjelaskan pola urutan dan mencari hubungan diantara dimensidimensi yang diuraikan. Disamping itu, kendati data telah disajikan bukan berarti proses analisis data sudah final.

\section{HASIL DAN PEMBAHASAN Hasil Penelitian}

Penelitian tentang penggunaan media kartu angka untuk meningkatkan kemampuan kognitif (berhitung) pada anak usia dini penelitian yang obyek penelitiannya digali melalui beragam informasi kepustakaan baik itu buku, ensiklopedi, jurnal ilmiah, koran, majalah, dan dokumen-dokumen lainnya yang berhubungan dengan media kartu angka untuk meningkatkan kemampuan kognitif (berhitung) pada anak usia dini (Saodah, 52:2010).

Objek penelitian yang digali dalam penelitian ini adalah Pertama DATA A.1. Artikel : Yarli Widya, Judul. Peningkatan Kemampuan Kognitif Melalui Permainan Angka di Raudhatul Athfal Al Muttaqin Kabupaten Agam. Kedua, DATA A.2. Jurnal : Akhmad Nayazik, Joko Suwignyo, Fara Meidika. Judul, Peningkatan Kemampuan Kognitif Dalam Mengurutkan Lambang Bilangan Melalui Media Kartu Angka. Ketiga, DATA A.3. Jurnal : Ni Putu Widi Dwi Artini, I Nengah Suadnyana dan I Wayan Wiarta, Judul. Penerapan Metode Bermain Berbantuan Media Kartu Angka Bergambar Untuk Meningkatkan Kemampuan Kognitif Paud Kusuma 2.

Hasil penelitian Kode data A1 skor pretes menunjukan data dari $43 \%$ menjadi $77 \%$ dengan selisih peningkatan $34 \%$. Kode data A2 menunjukan dari $50 \%$ menjadi $80 \%$ dengan selisih peningkatan $30 \%$. Kode data A3 dari $75 \%$ menjadi $89 \%$ dengan selisih 26\%. Rata-rata hasil pencapaian dari ketiga judul yang 
dianalisis sebelum menggunakam model pembelajaran media Kartu Angka yaitu $56 \%$ meningkat menjadi $82 \%$ dengan selisih rata-rata menjadi $26 \%$.

Kualifikasi dan Tujuan Penulisan. Kualifikasi, Kode Data A1 (Pendidikan Guru-Pendidikan Anak Usia Dini), Kode Data A2 (Pendidikan Guru-Pendidikan Taman Kanak-kanak) dan Kode Data A3 (Pendidikan Guru-Pendidikan Anak Usia Dini). Tujuan Penulisan, Kode Data A1, Tujuan Penelitian ini adalah untuk meningkatkan kemampuan Kognitif melalui permainan angka di Raudhatul Athfal Al-Muttaqin Kabupaten Agam, Kode Data A2, Kode Data A1, Tujuan Penelitian ini adalah untuk peningkatan kemampuan kognitif dalam mengurutkan lambang bilangan melalui media kartu angka dan Kode Data A3, Tujuan yang ingin dicapai dalam penelitian ini adalah untuk mengetahui penerapan metode bermain berbantuan media kartu angka bergambar untuk meningkatkan kemampuan kognitif paud kusuma 2.

Simpulan Hasil Analisis dari Rujukan

Dari hasil yang didapatkan bahwa perkembangan kognitif dalam kegiatan permainan media kartu angka bergambar bahwa terdapat peningkatan kognitif dari $75 \%$ menjadi $89 \%$ dengan selisih $26 \%$. Artinya dengan menggunakan media kartu angka bergambar dapat meningkatkan kognitif pada anak usia dini.

Adapun hasil peningkatan pembelajaran dari ketiga literatur dengan metode pembelajaran yang menggunakan media kartu angka untuk meningkatkan kemampuan kognitif (Berhitung) pada anak usia dini tersebut.

Dari literatur yang dianalisis dari sisi meotologi dan hasil yang telah dirangum dan ditulis dengan dengan melewati proses penelitian, baik penelitian lapangan, ataupun penelitian pustaka (Library Research), sedangkan artikel non penelitian adalah artikel yang ditulis tanpa melalui proses penelitian. Artikel non penelitian bersifat subjektif, tetapi tetap menggunakan tata cara penulisan sesuai pedoman ilmiah (Hamzah, 49:2020). Kegunaan sumber yang dirujuk dalam menjawab permasalahan.

Pendekatan pembelajaran dengan menggunakan kartu angka dilihat dari penelitian literatur di atas menunjukan adanya peningkatan kemampuan kognitif bagi anak usia dini dibandingkan dengan sebelum menggunakan media tersebut. Peningkatan kemampuan kognitif bagi anak usia dini sangat penting karena diusia ini menunjukan bahwa ia berada pada taraf praoprasional sampai samap tahap oprasional konkrit. Kemampuan Kognitif merupakan perkembangan pikiran. Pikiran adalah bagian dari proses berpikirnyadari otak, pikiran yang digunakan untuk mengenali, memberikan alasan rasional, mengatasi dan memahami kesempatan penting (Hasnida, 14:2014).

Jadi pedekatan media pembelajaran dengan menggunakan media kartu angka untuk meningkatkan kemampuan kognitif (berhitung) anak usia dini sangat tepat untuk dikembangkan sebagai acuan media membejaran yang efektif untuk meningkatkan kemampuan anak usia dini.

\section{Pembahasan}

Dilihat dari hasil analisis literaturliteratur diatas menunjukan bahwa data $\mathrm{A} 1$ hasil persentasi dari $43 \%$ menjadi $77 \%$ dengan selisih peningkatan $34 \%$ data A2 hasil persentasi dari $50 \%$ menjadi $80 \%$ dengan selisih peningkatan $30 \%$, data A3 hasil persentasi $75 \%$ menjadi $89 \%$ dengan selisih $26 \%$.

Dengan nilai rata-rata keseluruhan dari literatur yang dijadikan bahan penelitian dengan skor Pretes 56\% meningkat menjadi $82 \%$ dengan selisih rata-rata menjadi $26 \%$. Jadi dari hasil penelitian literatur dengan pendekatan pembelajaran 
pengguna media kartu angka untuk meningkatkan kemampuan kognitif (Berhitung) Anak usia dini meningkat dengan selisih $26 \%$.

Adapun temuan-temuan dalam penelitian literatur yang terkait dengan pendekatan pembelajaran yang menggunakan media kartu angka untuk meningkatkan kemampuan kognitif (berhitung) anak usia dini adalah. Pertama Dengan pendekatan pembelajaran yang menggunakan media kartu angka mejadi lebih menarik perhatian seorang anak karena memiliki bentuk, gambar dan warna yang berbeda-beda. Sehingga dengan media tersebut anak lebih mudah memahmi dan dimengerti, dan tentunya ini sangat berpengaruh terhadap peningkaan kemampuan kognitif pada anak usia dini. Kedua, Pendekatan pembelajaran yang menggunakan media kartu angka ini memudahkan kepada pengajar (Guru) dalam proses penyampain materi yang akan disampaikan kepada anau usia dini. Karena diusia anak yang seumur itu sangat membutuhkan alat peraga utuk membatu proses mengenalkan dan pemahami angkaangka terhadapa anak.

Ketiga Dalam Pendekatan pembelajaran yang menggunakan media kartu angka membuat suasan kelas menjadi riang gembira tidak tegang terhadap anak. Karena proses pembelajaran anak usia dini harus dibarengi dengan permainan (bermain sambil belajar) agar proses penyampaian materi bisa dan mudah dipahami oleh ank usia dini.

\section{PENUTUP}

\section{Simpulan}

Pendekatan pembelajaran dengan media Penggunaan Media Kartu Angka Untuk Meningkatkan Kemampuan Kognitif (Berhitung) Pada Anak Usia
Dinidengan metode penelitan kepustakaan (LibraryResearch) dapat disimpulkan bahwa: Pertama, Bahwa penggunaan media kartu angka dapat diterapkan pada anak usia dini dan dapat meningkatkan kemampuan kognitif (berhitung) pada anak usia dini. Kedua, Hasil dari penelitian menunjukan bahwa data A1 hasil persentasi dari $43 \%$ menjadi $77 \%$ dengan selisih peningkatan $34 \%$ data A2 hasil persentasi dari $50 \%$ menjadi $80 \%$ dengan selisih peningkatan $30 \%$, data A3 hasil persentasi $75 \%$ menjadi $89 \%$ dengan selisih 26\%. Dengan nilai rata-rata keseluruhan dari literatur yang dijadikan bahan penelitian dengan skor Pretes 56\% meningkat menjadi $82 \%$ dengan selisih rata-rata menjadi $26 \%$.

Jadi dari hasil penelitian literatur dengan pendekatan pembelajaran pengguna media kartu angka untuk meningkatkan kemampuan kognitif (Berhitung) Anak usia dini meningkat dengan selisih 26\%. Artinya bahwa penggunaan media kartu angka dapat meningkatkan kognitif (berhitung) secara signifikam pada anak usia dini.

\section{Saran}

Pertama, Bagi Lembaga pihak lembaga yang terkait menambah penyediakan sarana dan prasarana pembelajaran yang dapat menunjang dan meningkatkan hasil belajar pada anak didik. Kedua, Bagi Peneliti Selanjutnyadiharapkan penggunaan metode dan media pembelajaran yang menarik dan tepat sasaran dalam kegiatan pembelajaran sangat mempengaruhi minat dan ketuntasan belajar anak didik dalam meningkatkan prestasi belajarnya.

\section{Daftar Pustaka}

Amir Hamzah. (2020). Metode Penelitian Kepustakaan, Malang : Literasi Nusantara. Hal 49

Arikunto, Suharsimi. (2010). Prosedur

Penelitian. Jakarta: Renika Cipta. 
Asri Budiningsih. (2012). Belajar dan Pembelajaran, (Jakarta: PT. Rineka Cipta.

Asrori. (2007). Psikologi Pembelajaran. Bandung: Wacana Prima.

Cooper dan Taylor dalam Mohammad Imam Farisi. (2012). Artikel. Pengembangan Asesmen Diri Siswa (Student Self-Assessment) sebagai Model Penilaian dan Pengembangan Karakter. HEPI UNESA.

Desmita. (2009). Psikologi Perkembangan Peserta Didik. Bandung: Remaja Rosdakarya.

Diantama.Suarifqi. (2018). Metode Penelitian Pendidikan. Bandung: Pustaka Rahmat.

Dianne E. Papalia, Sally, \& Ruth, Human Develipment. (2010). Psikologi Perkembangan. Jakarta: Kencana.

Djaali. (2011). PsikologiPendidikan, Jakarta: Bumi Aksara.

Fadillah. (2017). Bermain dan Permainan Anak Usia Dini. Jakarta: Kencana.

Fadillah. (2017). Bermain dan Permainan Anak Usia Dini. Jakarta: Kencana.

Hartinah, Sitti. (2010). Pengembangan Peserta Didik. Bandung. Reflika Aditama. Hal 36.

Hasnida. (2014). Kebutuhan Anak Usia Dini. PT Luxima Metro Media. Jakarta Timur.

Kartini, (2011). Peningkatan Kemampuan Anak Mengenal Huruf Melalui Metode Bermain Kartu Kata. Bandung: Remaja Rosdakarya.

Latif, Mukhtar dkk. (2013). Orientasi Pendidikan Anak Usia Dini. Jakarta: Kencana Prenamedia Group.

Nunik Purwaningsih, Purwati, Halidah. (2009). Penggunaan Kartu Angka dalam Mengenal Konsep Bilangan Usia 5-6 tahun di Tk Negri Pembina Rasau Jaya (Skripsi Paud Untan Pontianak.

Peraturan Menteri Pendidikan dan Kebudayaan Republik Indonesia Nomor 137 Tahun (2014). Tentang
Standar Nasional Pendidikan Anak Usia Dini. Jakarta : Depdiknas

Peraturan Menteri Pendidikan Nasional Nomor 22 Tahun (2006). Tentang Standar Isi untuk Satuan Pendidikan Dasardan Menengah, Jakarta : Depdiknas.

Rohani. (2016). Mengoptimalkan Perkembangan Kognitif Anak Melalui Kegiatan Bermain Jurnal Paud, Vol, 1, No 2.

Sumanto. (2014). PsikologiPerkembangan. Yogyakarta: Center of Academic Publishing Service.

Susanto, A, (2011). Perkembangan Anak Usia Dini. Jakarta: Kencana Prenada Media Group.

The UCSC University Library. Write a Literature Review (http://guides.library.ucsc.edu/write -a-literature-review diaksestanggal 15 Mei 2020).

Upton, Penney. (2012). Psikologi Perkembangan. Jakarta: Erlangga.

Usman, M. Basyiruddin dan Asnawir. (2007). Media Pembelajaran. Jakarta: Ciputat Press.

W.S. Winkel. (2006). sikologiPengajaran. Jakarta: Gramedia Widia Sarana Indonesia.

Yamin, Martinis dan Jamilah Sabri Sanan. (2013). Panduan PAUD. Jakarta: Gaung Persada Press Group.

Zaman, Badru dkk. (2013). Media dan Sumber Belajar TK. Tanggerang Selatan: Universitas Terbuka. 